\title{
Salinity Status of Lajas Valley Soils
}

\author{
Juan A. Bonnet and Eduardo J. Brenes ${ }^{1}$
}

\section{INTRODUCTION}

Puerto Rico, the smallest of the four islands of the Greater Antilles in the Caribbean Area, lies south of the Tropic of Cancer between $17^{\circ} 55^{\prime}$ and $18^{\circ} 31^{\prime} \mathrm{N}$. and between $65^{\circ} 39^{\prime}$ and $67^{\circ} 15^{\prime} \mathrm{W}$. In its southwestern arid area lies the Lajas Valley, that measures from 0.5 to 2 miles in width from North to South and from 20 to 22 miles in length from East to West. It is bounded by mountains on the North (fig. 1) and South.

In the Post-Glacial Quaternary epoch of the Pleistocene period, the Valley was a salty-water canal connecting the Atlantic Ocean in the West and the Caribbean Sea in the Southeast. The area was later raised by geologic forces and the Valley was filled with alluvial tuffaceous and ashy-shale detritus washed mostly from the mountains at the North. Two lagoons, one at the East and a smaller one at the West, filled the lower depressions. The run-off waters travel now into and through the long axis of the Valley; about two-thirds drains into the Caribbean Sea and about one-third into the Atlantic Ocean.

The mean annual rainfall is about 31 inches and is poorly distributed. Evaporation losses generally exceed rainfall from winter to summer. The crops suffer from drought generally throughout the year, and from excess of rainfall at some periods between summer and winter, when an excess of rainfall causes flooding or water-logging conditions owing to slow rates of discharge and percolation of the run-off waters. Brackish or salty waters for cattle use in Lajas Valley have been or are pumped by windmills (fig. 2) from several places.

A multiple-purpose project covering hydroelectric power, irrigation, (fig. 3), drainage (figs. 4 and 5), and water supply is now being constructed in that area. When finished, fresh waters will be available to irrigate about 26,000 acres in Lajas Valley.

Description of the soils and salinity problems of Lajas Valley have been discussed and published by Bonnet and Tirado Sulsona (1).2

${ }^{1}$ Head and Assistant Soil Scientist, respectively, Soils Department, Agricultural Experiment Station, University of Puerto Rico, Río Piedras, P. R. The writers wish to express their acknowledgments to M. A. Lugo-López, Associate Soil Scientist; G. Acevedo and R. Pérez Escolar, Research Assistants in Soils, for taking the soil samples; and to G. García Monge and G. Malaret, Research Assistants in Chemistry, for their cooperation in the chemical work.

2 Italic numbers in parentheses refer to Literature Cited, p. 34. 


\section{FIELD SURVEY AND SOIL SAMPLING}

One-inch squares with sides oriented North-South and East-West, respectively, were ruled on base maps (fig. 6) on a scale of $1: 10,000$. The sides of each square represented roughly 835 feet and each square represented about 16 acres. Letters and numbers were used as coordinates to identify the corners of the squares. Soil samples (figs. 7 and 8) were taken with a soil auger at two depths: 0 to 8 and 8 to 24 inches, respectively, at

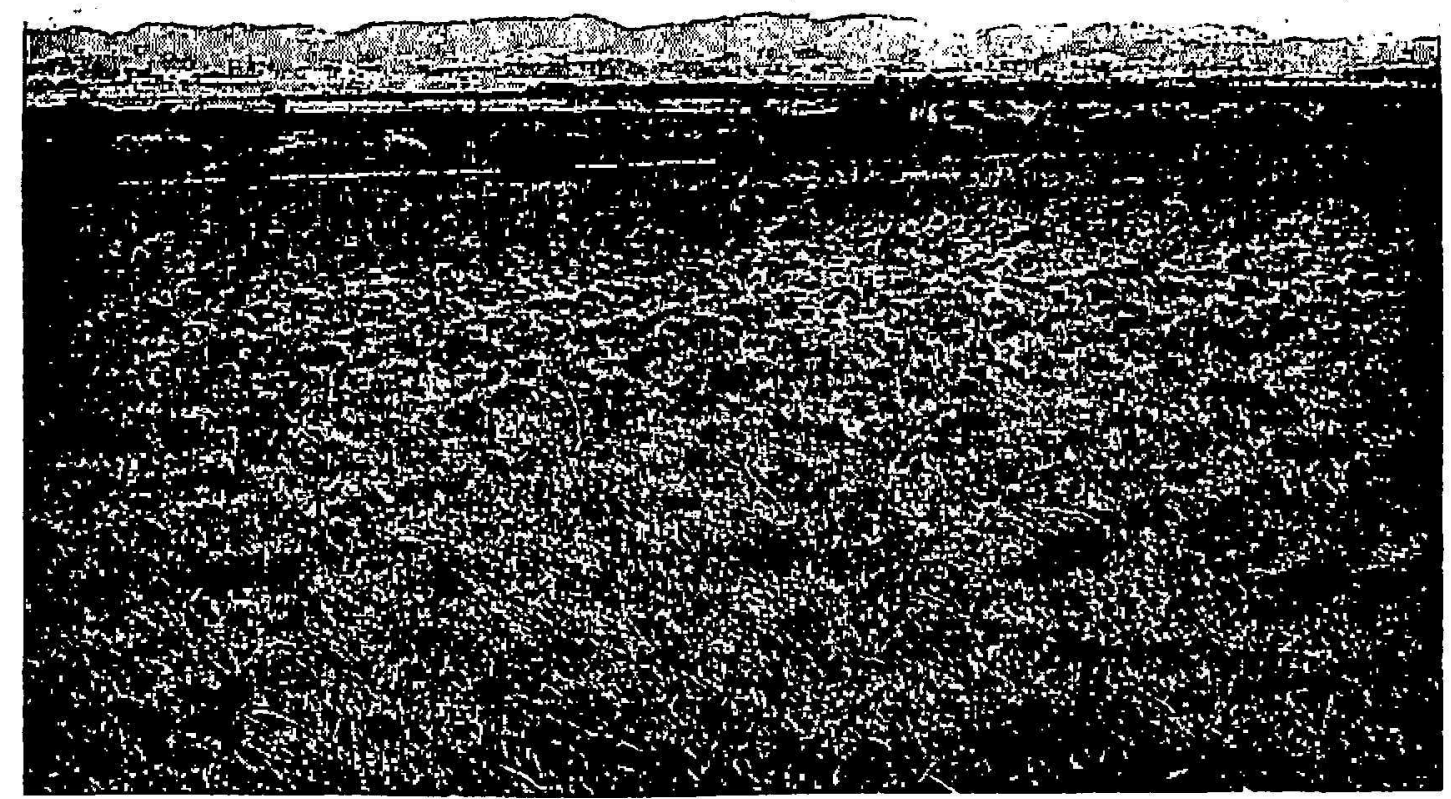

FIG. 1-The general landscape of Lajas Valley showing mountains in the North.

the field locations corresponding to the corners of the squares. Every four squares, or for about every 64 acres, two more samples were also taken, at depths of 24 to 48 and 48 to 72 inches, respectively.

The soil samples were air-dried and ground in a corn mill. Water-saturation extracts were prepared for laboratory analyses by methods recommended by the U. S. Regional Salinity Laboratory (2). The following determinations were made: Soil $\mathrm{pH}$, moisture at soil-saturation point, electrical conductivity, and calcium-magnesium soluble in the water extract. The water-soluble sodium was calculated from the laboratory data. The soluble cations were expressed in milliequivalents per liter. The 
exchangeable-sodium percentage was obtained from a nomogram using the data obtained, respectively, for water-extractable sodium and for water-extractable calcium-plus-magnesium.

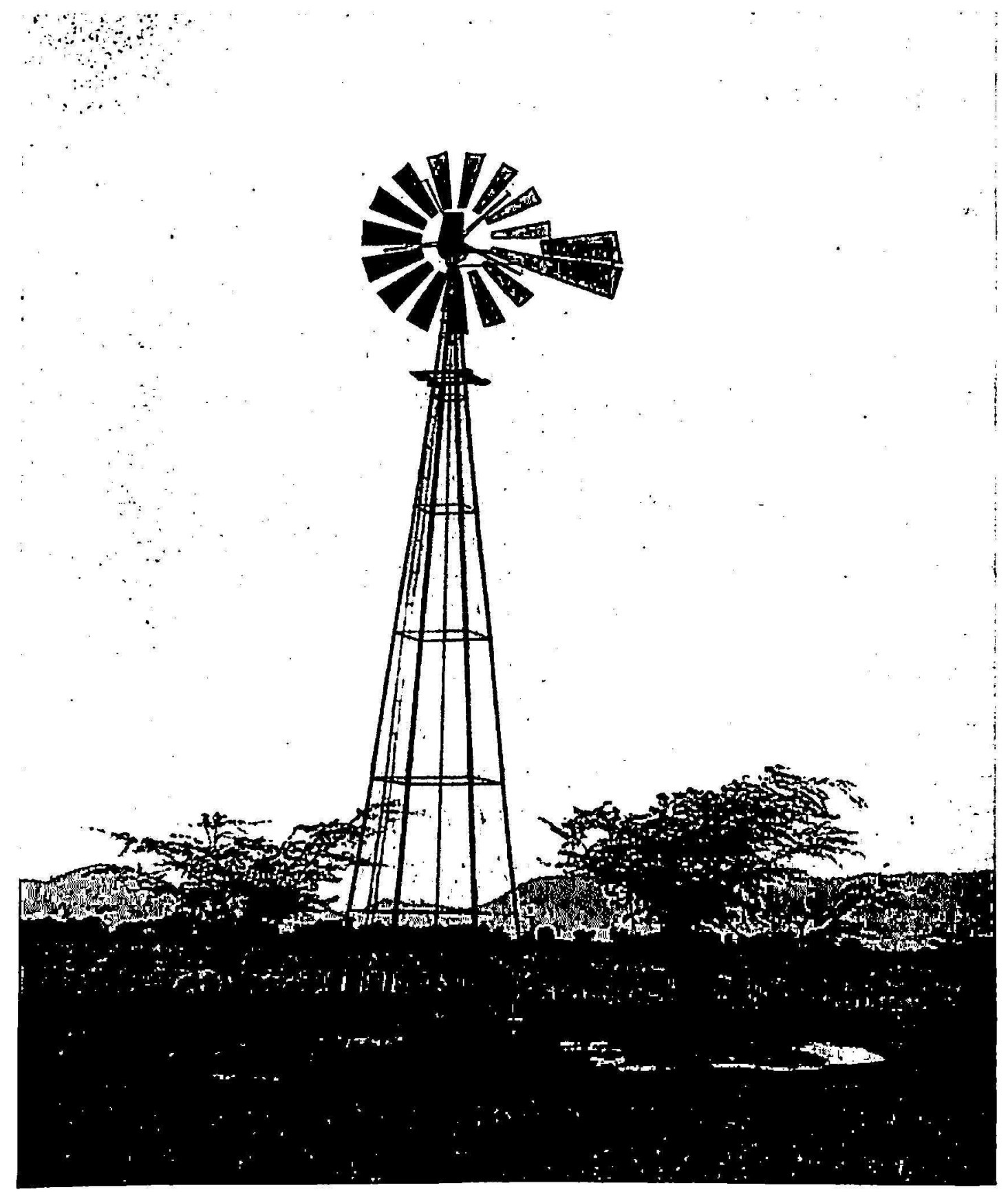

Fig. 2-Windmills are seattered around Lajas Valley farms.

The soils of the area studied were grouped into four classes: Normal, saline, saline-alkali, and nonsaline-alkali, based on the ranges for the values of electrical conducitivity, exchangeable-sodium percentage, and soil $\mathrm{pH}$ given in table 1 . 


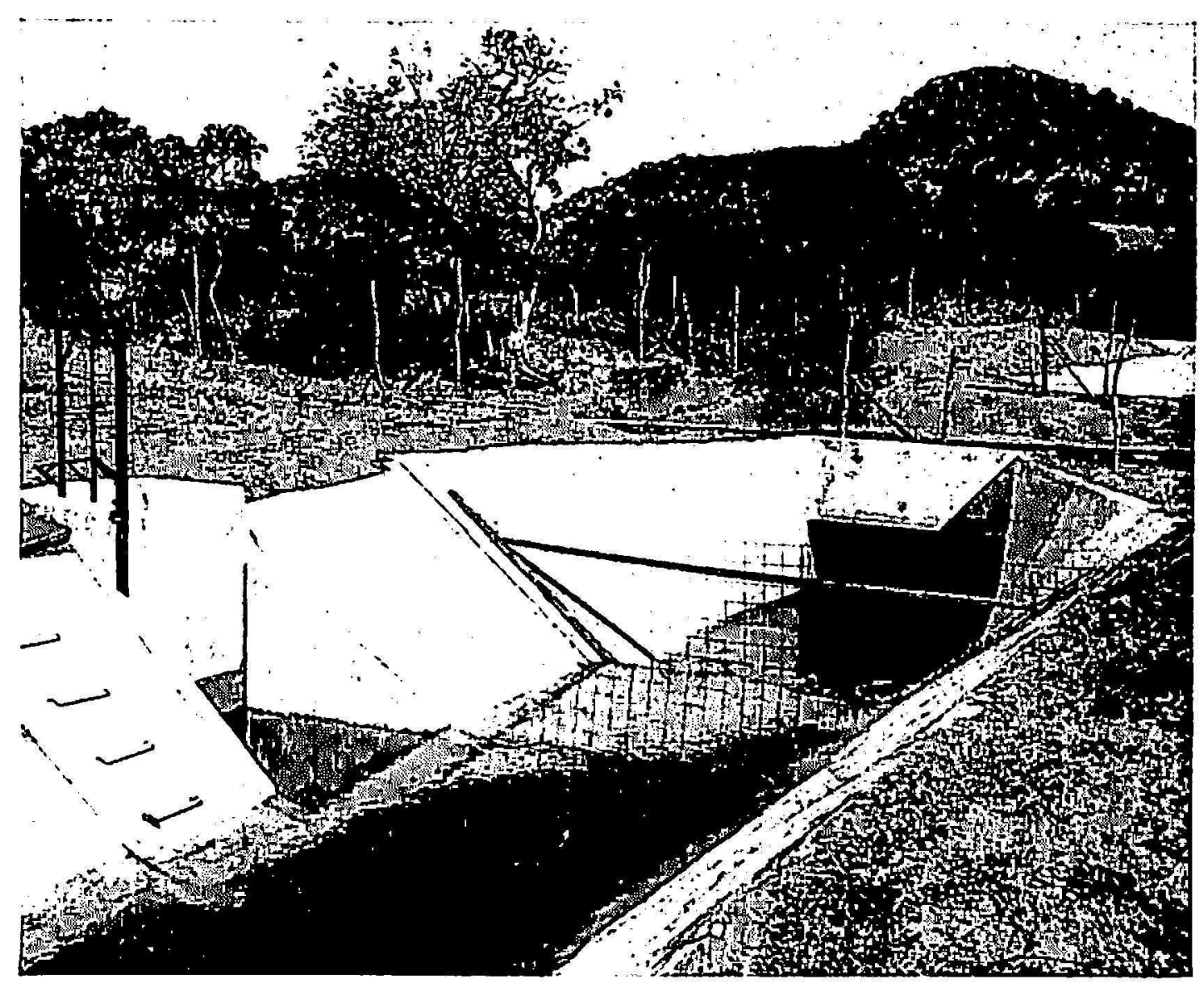

FIG. 3-Part of main northern irrigation canal with gate at the side; Lajas Valley.

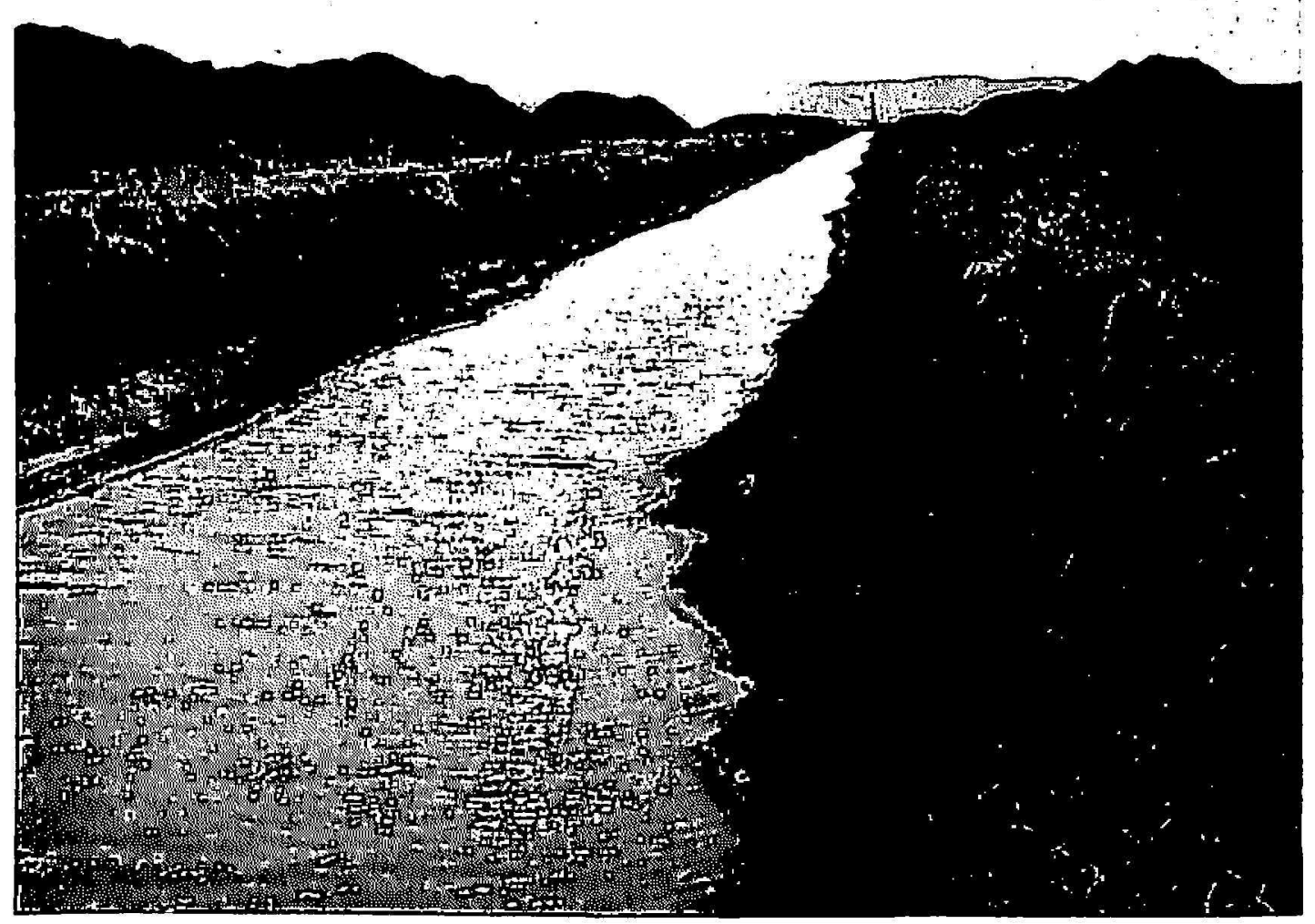

Fig. 4-Part of main southern drainage canal in Jajas Valley. 


\section{PRESENTATION OF DATA}

A total of 1,541 locations representing about 24,656 acres $^{3}$ of the area were sampled at depths of 0 to 8 and 8 to 24 inches, respectively. This area included 439 locations sampled also at depths of 24 to 48 and 48 to 72 inches, respectively.

The percentages of normal, saline, saline-alkali, and nonsaline-alkali soils, per depth of sampling, are reported in table 2 .

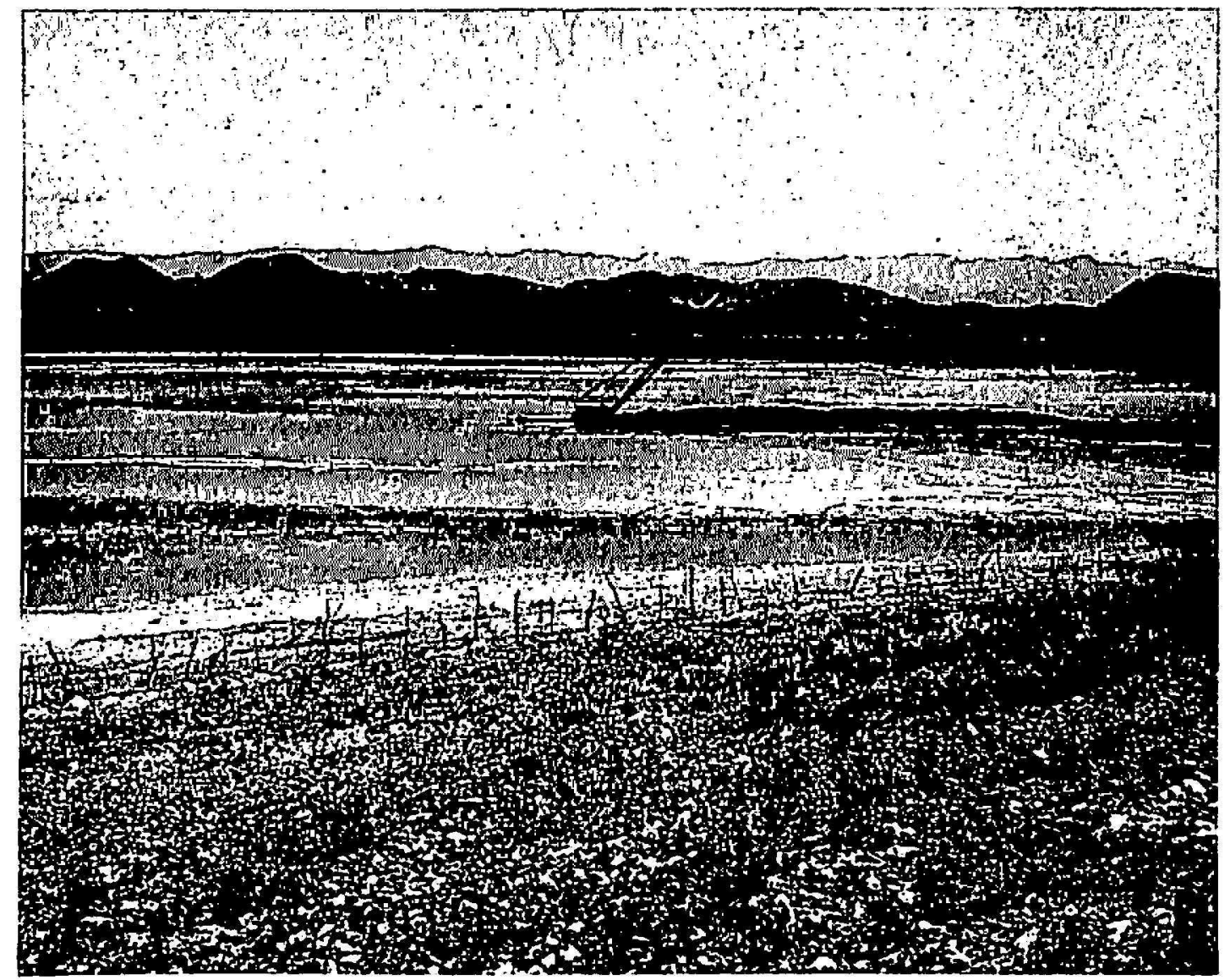

FIG. 5-Mechanical shovel digging drainage canal for drying the Guánica Iagoon at the eastern part of Lajas Valley to carry excess run-off waters.

The values for saturation percentage (SP), electrical conductivity (EC), exchangeable-sodium percentage (ESP), soil $\mathrm{pH}$, gypsum content, gypsum requirement, and hydraulic conducivity (K), are given in table 3 for various layers of four soil profiles of the Lajas Valley. The hydraulic conductivity was determined in undisturbed soil samples taken with a 4 -inch cylindrical core. The soil layers (table 3) are also classified into normal, saline-alkali, and nonsaline-alkali soils.

${ }^{3}$ A report for 11,230 acres was submitted to the Sixth International Congress of Soil Science, held in Paris Aug. 29 to Sept. 8, 1956. 


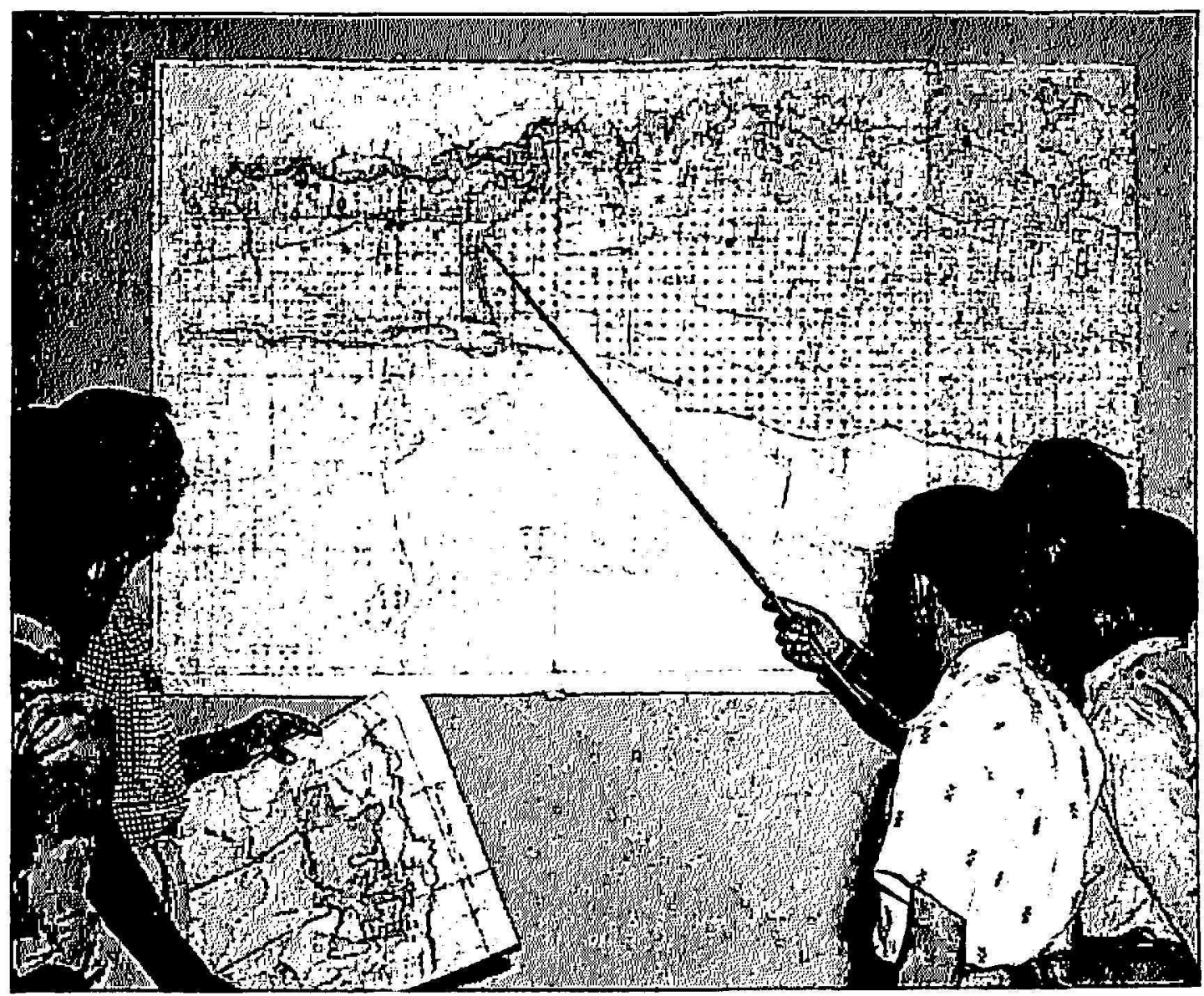

Fig. 6-Fxamining map of Lajas Valley showing locations for soil sampling.

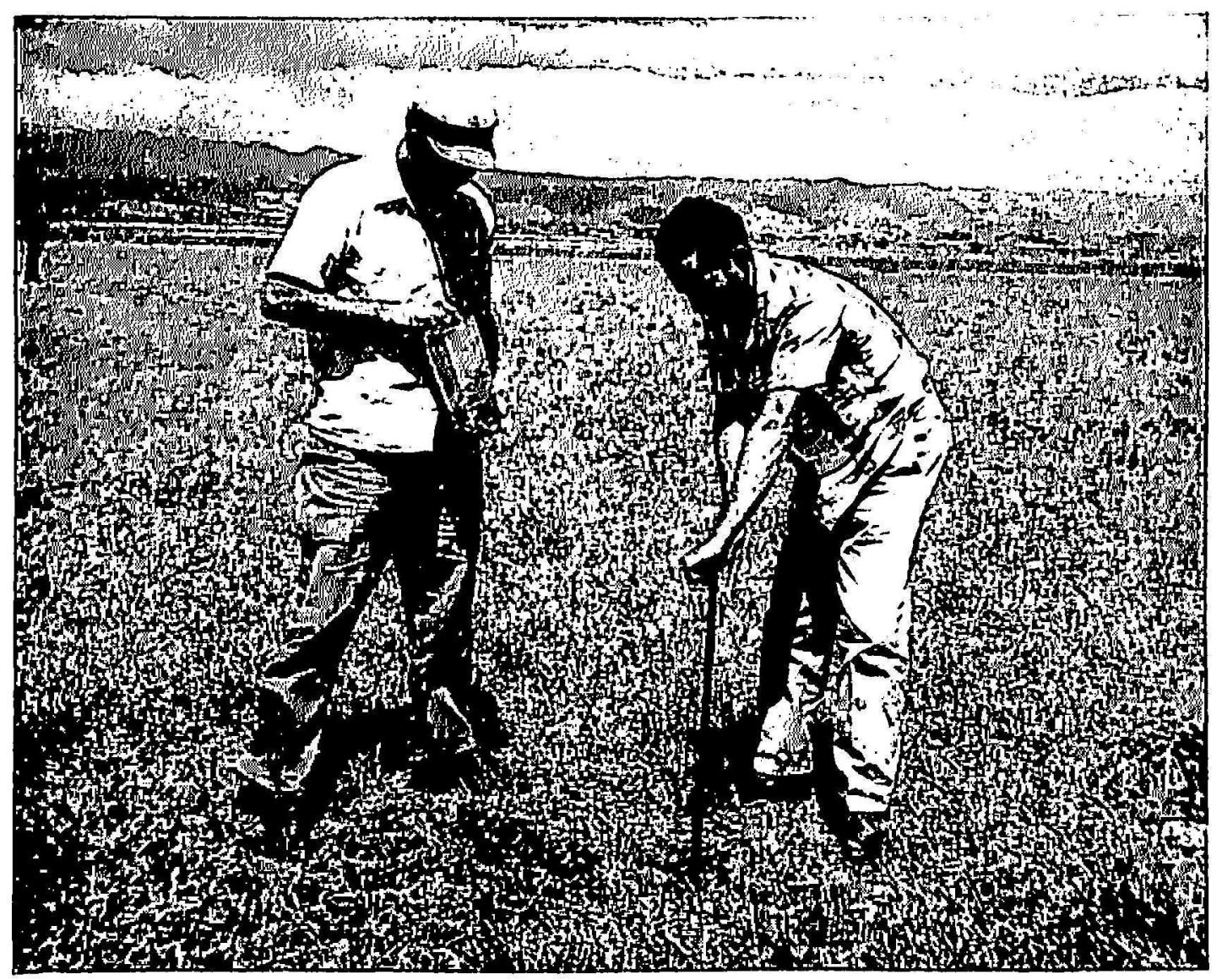

FIG. 7-Taking soil samples in dry areas. 


\section{SUMMARY}

1. The area of soils surveyed in Lajas Valley was 24,656 acres.

2. The soils were classified into normal, saline, saline-alkali, and non-

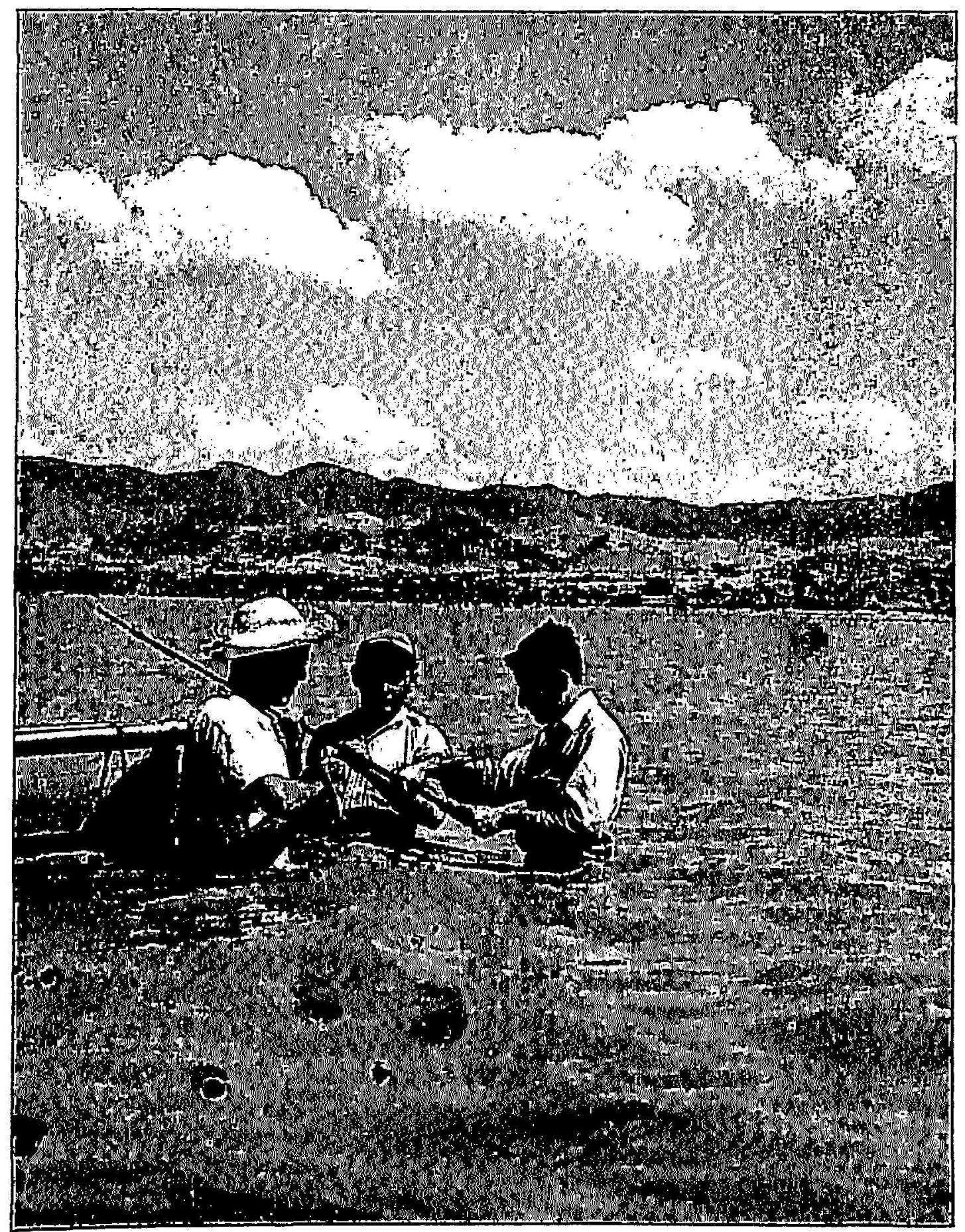

Fig. 8-Taking soil samples from under water of the Guanica lagoon.

saline-alkali (table 1) at depths of 0 to 8,8 to 24,24 to 48 , and 48 to 72 inches, respectively.

3. A large percentage of normal soils was found in the upper soil layer and of saline-alkali soils in the lower layers (table 2). 
4. Normal soils occupied about 86 percent of the surface area to a depth of 8 inches and about 63 percent at a depth of 8 to 24 inches.

5. Soils with a salinity problem (table 2 ) increased from 9 percent at a depth of 8 inches to $28.3,58.8$ and 68.5 percent, respectively, at depths of 8 to 24,24 to 48 , and 48 to 72 inches.

6. The soils with a salinity problem were largely of the saline-alkali class (table 1).

TABLE 1.-Classification of normal, saline, saline-alkali, and nonsalinc-alkali soils ((2) $p p$. 4-6))

\begin{tabular}{|c|c|c|c|}
\hline Soil class & $\begin{array}{c}\text { Electrical conduc- } \\
\text { tivity (EC) of satura- } \\
\text { tion extract in millim- } \\
\text { hos } / \text { centimeter at } \\
25^{\circ} \mathrm{C}\end{array}$ & $\begin{array}{c}\text { Exchangcable } \\
\text { sodium percentage } \\
\text { (ESP) in the soil }\end{array}$ & Soil pH \\
\hline $\begin{array}{l}\text { Normal } \\
\text { Saline } \\
\text { Saline-alkali } \\
\text { Nonsaline-alkali }\end{array}$ & $\begin{array}{l}\text { Less than } 4.0 \\
4 \text { or higher } \\
4 \text { or higher } \\
\text { Less than } 4.0\end{array}$ & $\begin{array}{l}\text { Less than } 15 \\
\text { Less than } 15 \\
15 \text { or higher } \\
15 \text { or higher }\end{array}$ & $\begin{array}{l}\text { Generally less than } 8.5 \\
\text { Usually less than } 8.5 \\
\text { Seldom higher than } 8.5 \\
\text { Usually between } 8.5 \text { and } 10.0\end{array}$ \\
\hline
\end{tabular}

TABLE 2.-Percentages of normal, saline, saline-alkali, and nonsaline-alkali soils according to depth of sampling in 24,656 acres surveyed and sampled in Lajas Valley

\begin{tabular}{c|c|c|c|c}
\hline $\begin{array}{c}\text { Depth of sampling } \\
\text { (inch) }\end{array}$ & Normal & Saline & Saline-alkali & Nonsaline-alkali \\
\cline { 2 - 3 } & Percent & Percent & Percent & Percent \\
0 to 8 & 85.8 & 5.2 & 7.5 & 1.5 \\
8 to 24 & 63.4 & 8.3 & 20.2 & 8.1 \\
24 to 48 & 33.5 & 7.7 & 48.5 & 10.3 \\
48 to 72 & 24.0 & 7.5 & 58.1 & 10.4 \\
\hline
\end{tabular}

7. In four soil-profile samples (table 3) taken from Lajas Valley, the saturation percentage varied from 58 to 191 , the electrical conductivity from 0.8 to 28.4 millimhos per centimeter, the exchangeable-sodium percentage from 2.2 to 46.0 , the soil $\mathrm{pH}$ from 8.1 to 8.9 , the content of gypsum from 0 to 21.9 tons per acre-foot, the gypsum requirement from 0 to 23.8 tons per acre-foot, and the hydraulic conductivity from less than 0.005 to 6.24 inches of water per hour. Higher gypsum contents were found in the deep subsoil layers of two soils (profiles 1 and 4). Amounts of gypsum varying from 9.9 to 20.3 tons per acre-foot of depth, are required for the reclamation of the surface layers of these two profiles. In general, the hydraulic-conductivity values show that the soil-surface layers are more permeable than the subsoil layers. 
8. The procedure and methods used in this paper were found to be accurate, simple, rapid, and practical. They are recommended for the coordination of data related to the classification and reclamation of soils affected by salinity problems in the different countries of the world.

TABLE 3.-Saturation percentage (SP), electrical conductivity (EC), exchangeablesodium percenlage (ESP), soil $p H$, soil class, gypsum content, gypsum requirement, and hydraulic conductivity $(K)$ of four soil profiles in Lajas Valley

\begin{tabular}{|c|c|c|c|c|c|c|c|c|c|}
\hline \multirow[b]{2}{*}{ Profile No. and soil } & \multirow[b]{2}{*}{ Depth } & \multirow[b]{2}{*}{ SP } & \multirow[b]{2}{*}{ EC } & \multirow[b]{2}{*}{ ESP } & \multirow[b]{2}{*}{ pH } & \multirow[b]{2}{*}{ Soil class } & \multicolumn{2}{|c|}{ Gypsum } & \multirow[b]{2}{*}{$\mathbf{K}$} \\
\hline & & & & & & & Content & $\begin{array}{l}\text { Re- } \\
\text { quire- } \\
\text { ment }\end{array}$ & \\
\hline \multirow{7}{*}{$\begin{array}{l}\text { 1. Fraternidad } \\
\text { clny }\end{array}$} & In. & & $\begin{array}{l}\text { Millimbos } \\
\text { per } \\
\text { certimeler }\end{array}$ & & & & $\begin{array}{l}\text { Tons/ } \\
\text { A.ff. }\end{array}$ & $\begin{array}{l}\text { Tons/ } \\
\text { A.-fi. }\end{array}$ & $I_{n}, / \| r_{0}$ \\
\hline & $0-10$ & 105 & 17.5 & 46.08 & 8.5 & Saline-alkali & 0 & 20.3 & 0.071 \\
\hline & $|10-26|$ & 89 & 28.0 & 40.78 & 8.4 & do. & 0 & 16.8 & .082 \\
\hline & $26-31$ & 85 & 28.2 & $39.9 \mid \varepsilon$ & 8.5 & do. & 0 & 21.7 & \\
\hline & $|31-42|$ & 88 & 28.2 & $36.3 \mid 8$ & 8.4 & do. & 14.6 & 5.7 & .057 \\
\hline & $42-66$ & 92 & 28.4 & 37.0 & 8.4 & do. & 8.6 & 6.4 & .044 \\
\hline & $|66-82|$ & 95 & 26.4 & $39.3 \mid \&$ & 8.5 & do. & 2.2 & 10.6 & .026 \\
\hline \multirow[t]{5}{*}{ 2. Aguirre clay } & $0-3$ & 88 & 2.0 & 3.0 & 8.3 & Normal & 0 & 0 & 6.240 \\
\hline & $3-12$ & $97 \mid$ & 1.2 & 5.18 & 8.4 & do. & 0 & 0 & 1.750 \\
\hline & $\mid 12-32$ & 152 & 1.3 & 16.0 & 8.9 & Nonsaline alkali & 0 & 13.4 & .025 \\
\hline & $|38-47|$ & 191 & 5.0 & 37.2 & 8.9 & Saline-alkali & 0 & 23.8 & .025 \\
\hline & $|47-70|$ & 160 & 6.8 & 45.0 & 8.8 & do. & 0 & 19.6 & .057 \\
\hline \multirow{5}{*}{$\begin{array}{l}\text { 3. Guánica silty } \\
\text { clay loam }\end{array}$} & $0-8$ & 84 & .8 & 2.2 & 8.1 & Normal & 0 & 0 & .033 \\
\hline & $8-19$ & 112 & 1.1 & 11.0 & $8.9 \mid$ & do. & 0 & 14.7 & .041 \\
\hline & $|19-26|$ & 128 & 2.0 & $\mid 12.5$ & 8.5 & do. & 0 & 20.3 & $<.005$ \\
\hline & $|26-42|$ & 130 & 6.0 & 24.5 & 8.3 & Saline-alkali & 0 & 21.7 & .018 \\
\hline & $42-72$ & 110 & 13.0 & 30.2 & 8.4 & do. & 1.1 & 18.2 & .013 \\
\hline \multirow{6}{*}{$\begin{array}{l}\text { 4. Fraternidad } \\
\text { clay loam }\end{array}$} & $|0-12|$ & 58 & 1.3 & 8.5 & 8.2 & Normal & 0 & 9.9 & .153 \\
\hline & $|12-25|$ & 68 & 5.5 & 23.0 & 8.8 & Saline-alkali & 0 & 14.0 & .049 \\
\hline & $25-31$ & 67 & 13.0 & 19.0 & 8.3 & do. & 20.1 & 13.4 & \\
\hline & $31-45$ & $72 \mid$ & 13.0 & $|18.2|$ & 8.4 & do. & 21.9 & 11.2 & .113 \\
\hline & $45-62$ & 96 & 6.0 & 28.1 & 8.8 & do. & 0 & 14.0 & .080 \\
\hline & $|62-72|$ & $92 \mid$ & 6.0 & $28.3 \mid$ & 8.8 & do. & 0 & 8.3 & .022 \\
\hline
\end{tabular}

\section{RESUMEN}

1. El area de los suelos estudiados y clasificados en el valle de Lajas comprende 24,656 acres.

2. Los suelos se clasificaron en normales, salinos, salinos-alcalinos y no salinos-alcalinos a profundidades de 0-8, 8-24, 24-48 y 48-72 pulgadas, respectivamente. (cuadro 1 ). 
3. El por ciento más alto de los suelos normales se encuentra en la capa superior del área estudiada y los salinos alcalinos en las inferiores.

4. Los suelos normales ocupan cerca del 86 por ciento del área hasta una profundidad de 8 pulgadas y alrededor del 63 por ciento a una profundidad de 8 a 24 pulgadas.

5. Los suelos con problemas de salinidad (cuadro 2) aumentaron desde el 9 por ciento, hasta 28,59 y 69 por ciento, respectivamente, a profundidades de 0-8, 8-24, 24-48 y 48-72 pulgadas.

6. Los suelos que tenían problemas de salinidad pertenecen principalmente a la clase salina alcalina (cuadro 1 ).

7. En las muestras que se tomaron de 4 perfiles de suelo (cuadro 3), el por ciento de saturación varió desde 58 a 191; la conductividad eléctrica de 0.8 a $28.4 \mathrm{mmhos} . / \mathrm{cm}$.; el por ciento de sodio intercambiable de 2.2 a 46.0; el pH del suelo de 8.1 a 8.9, el contenido de yeso de 0 a 21.9 ton/A./ pie; el requisito de yeso de 0 a 23.8 ton/A./pie; y la conductividad hidráulica desde menos de 0.005 a 6.24 pulgadas de agua por hora. Se encontraron altos contenidos de yeso en las capas profundas del subsuelo en dos suelos (perfiles 1 y 4). Para la reclamación de las capas superficiales de estos dos perfiles se necesita aplicar cantidades de yeso que fluctúen entre 9.9 y 20.3 ton/A./pie. En general, los valores de conductividad hidráulica señalan que las capas superficiales de los suelos son más permeables que las de los subsuelos.

8. Los resultados de este trabajo indican que el procedimiento y los métodos usados fueron exactos, simples, rápidos, y prácticos y se recomiendan para coordinar datos relacionados con la clasificación y reclamación de los suelos que son afectados por problemas de salinidad en los diferentes países del mundo.

\section{LITERATURE CITED}

1. Bonnet, J. A., and Tirado Sulsona, P., Soil studies in Lajas Valley, Agr. Exp. Sta., Univ. P. R., Bul. 86, 64 pp. with 15 tables and 10 figures, Aug. 1950.

2. Richards, L. A., et al., U. S. Salinity Laboratory Staff, Agr. Handbook No. 60, U. S. Dept. of Agr., 160 pp., Feb. 1954. 